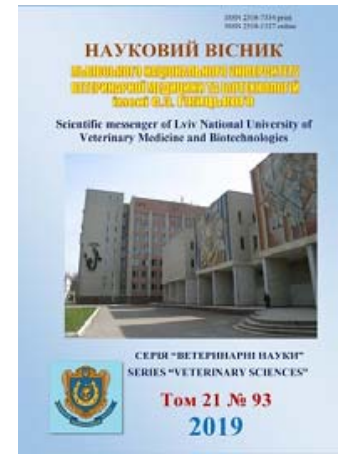

Науковий вісник Дьвівського національного університету ветеринарної медицини та біотехнологій імені С.3. Гжицького.

\author{
Серія: Ветеринарні науки
}

Scientific Messenger of Lviv National University of Veterinary Medicine and Biotechnologies. Series: Veterinary sciences

UDC 619: 576.5

\title{
Investigation of the minimum bactericidal concentration of acid detergent "Milkodez" on the test culture of microorganisms
}

\author{
M.M. Verkholiuk \\ Stepan Gzhytskyi National University of Veterinary Medicine and Biotechnologies Lviv, Ukraine
}

Article info

Received 28.01.2019

Received in revised form 12.03 .2019

Accepted 13.03.2019

Stepan Gzhytskyi National University of Veterinary Medicine and Biotechnologies Lviv, Pekarska Str., 50, Lviv, 79010, Ukraine. Tel.: +38-097-466-86-32 E-mail:verholuk@ukr.net
Verkholiuk, M.M. (2019). Investigation of the minimum bactericidal concentration of acid detergent "Milkodez" on the test culture of microorganisms. Scientific Messenger of Lviv National University of Veterinary Medicine and Biotechnologies. Series: Veterinary sciences, 21(93), 93-97. doi: $10.32718 /$ nvlvet9316

The main task of the dairy industry is the production of raw milk, the quality of which depends on the degree of bacterial background of milk and is achieved only if the regular cleaning and disinfection of milking equipment, dairy equipment. Milk is a good nutrient for microorganisms. The safety of milk that is obtained in dairy complexes provides for acceptable standards in its composition of any chemical, physical or biological substances that pose a potential threat to human health. The largest share of the listed factors belongs to microbiological contamination. The purpose of the work was to investigate the minimum bactericidal concentration of the acid detergent "Milkodez" on the test culture of microorganisms: S. aureus ATCC 25923, E. coli 055K59 No. 3912/41, P. aeruginosa 27/99. The study found that the acid "Milkodez" has bactericidal activity on the $S$. aureus culture test at dilution of a disinfectant 1: 268.8 and less and an active substance concentration of $0.371 \%$ or more at exposure of 2 minutes, for breeding 1:376, 5 and less (concentration of the active substance 0.265\% and more) at exposure of 5 minutes and at dilution 1:1466.3 and less and a concentration of $0.0691 \%$ or more for 15 minutes. Minimal bactericidal concentration of the acid "Milkodez" on the test of E. coli culture at an exposure of 2 minutes amounted to 0.134\%, at an exposure of 5 minutes. $-0.0493 \%$ and 15 minutes $-0.0352 \%$. When the concentration of the agent is $0.012856 \%$ or more and its dilution is 1:7778.4 and less, throughout all investigated time ranges, there is no growth of the test culture P. aeruginosa. The use of the product at a temperature of $70 \pm 5{ }^{\circ} \mathrm{C}$ allowed to inhibit the golden staphylococci at the concentration of the solution of the drug $0.371 \%$ for 2 minutes of action and $0.265 \%$ and $0.0691 \%$ - respectively within 5 and 15 minutes. At the same time, at the temperature of the solution of the Milkodez solution $70 \pm 5{ }^{\circ} \mathrm{C}$, the death of the E. coli was observed at the concentration of the acidic substance $0.0352 \%, 0.0493 \%$ and $0.134 \%$, respectively, for 2, 5 and 15 minutes. The increase in the temperature of the solution from $20 \pm 5{ }^{\circ} \mathrm{C}$ to $70 \pm 5{ }^{\circ} \mathrm{C}$ resulted in the death of $P$. aeruginosa bacteria at a concentration of $0.01285 \%$ in all time ranges.

Key words: acid Milkodez, S. aureus, E. coli, P. aeruginosa, bactericidal action.

\section{Дослідження мінімальної бактерицидної концентрації кислотного мийно-дезінфікуючого засобу “Мілкодез” на тест-культурах мікроорганізмів}

\author{
М.М. Верхолюк
}

Львівський національний університет ветеринарної медицини та біотехнологій імені С.3. Гжиџького, м. Львів, Украӥна

Основним завданням молочної промисловості є виробнищтво сирого молока, якість якого залежить від ступеня бактеріального фону молока і досягається лише за умови регулярного очищення та дезінфекиії дойльного обладнання, молочного інвентаря. Молоко є добрим поживним середовищем для мікроорганізмів. Безпечність молока, щзо отримується на молочних комплексах передбачає допустимі норми в його складі будь-яких хімічних, фізичних або біологічних речовин, які становлять потенційну загрозу 
здоров'ю людини. 3 перелічених чинників найбільша питома частка належить мікробіологічним забрудненням. Метою роботи було дослідити мінімальну бактерицидну концентрацію кислотного мийно-дезінфікуючого засобу “Мілкодез” на тест-культури мікроорганізмів: S. aureus ATCC 25923, E. coli 055K59 №3912/41, Р. aеruginosa 27/99. В результаті дослідження встановлено, изо кислотний засіб “Мілкодез” володіє бактерицидною активністю на тест-культуру S. аитеи при розведені дезінфектанта 1:268,8 і менше та концентрації діючої речовини 0,371\% $і$ більше за експозиції 2 хв, за розведення 1:376,5 і менше (концентрація діючої речовини 0,265\% і більще) при експозиції 5 хв та при розведенні 1:1466,3 і менше та концентрації 0,0691\% $і$ більще протягом 15 хвилин. Мінімальна бактерицидна концентрація кислотного засобу “Мілкодез” на тест- культуру E. соді за експозиції 2 хв становила 0,134\%, за експозиціі 5 хв - 0,0493\% та 15 хв - 0,0352\%. При концентрації засобу 0,012856\% $і$ більще та його розведенні 1:7778,4 і менше протягом всіх досліджуваних часових діапазонів відмічаємо відсутність росту тест-культури Р. аетияіпова. Застосування засобу за температури $70 \pm 5{ }^{\circ} \mathrm{C}$ дозволяло інгібувати золотистий стафілокок за кониентрації розчину засобу 0,371\% протягом 2 хвилин дї та 0,265\% і 0,0691\% - відповідно протягом 5 i 15 хвили. В той же час за температури розчину засобу “Мілкодез” $70 \pm 5{ }^{\circ} \mathrm{C}$ загибель кишкової палички спостерігали за концентрацї кислотного засобу 0,0352\%, 0,0493\% та 0,134\% відповідно протягом 2, 5 та 15 хв. Підвищення температури розчину з $20 \pm 5{ }^{\circ} \mathrm{C}$ до $70 \pm 5{ }^{\circ} \mathrm{C}$ призводило до загибелі бактерій P. aeruginosa за концентрації засобу 0,01285\% в усіх часових діапазонах.

Ключові слова: кислотний засіб “Мілкодез”, S. aureus, E. coli, P. aeruginosa, бактерицидна дія.

\section{Вступ}

Молоко є поживним середовищем, яке може бути легко забруднено мікроорганізмами (Kryzhanivskyi et al., 2005; Zazharska, 2016). Безпечність молока, що отримується на молочних комплексах передбачає відсутність в його складі будь-яких хімічних, фізичних або біологічних речовин, які становлять потенційну загрозу здоров'ю людини, але найбільшу загрозу виробництву молока становлять мікробіологічні чинники (Palii \& Synytsia, 2016; Bogatko et al., 2018). За останні роки виробництво якісного та безпечного сирого молока як продукту для населення та харчової промисловості залишається у нашій країні вагомою проблемою (Berhilevych et al., 2010; Gachak et al., 2017).

Використання машинних апаратів для доїння, транспортування, обробки та зберігання молока призвело до збільшення поверхонь, із якими контактує молоко на своєму шляху від вимені до виходу його із ферми. Крім того зазвичай усі поверхні, 3 якими контактує молоко при його транспортуванні та первинній переробці, $є$ замкнутими та недоступними для відкритої очистки й дезінфекції. В процесі доїння на цій поверхні утворюються ліпідно-протеїнові забруднення, які служать відмінним середовищем для розвитку мікроорганізмів. При недостатньо ефективному видаленні забруднень і дезінфекції, які знаходяться у молокопроводі, чисельність мікрофлори збільшується у декілька тисяч разів. Більша частина цих бактерій потрапляє у наступну партію молока, суттєво погіршуючи показники його санітарно-гігієнічної якості (Karpent'er er al., 2008; Pushkar, 2014).

Основним завданням молочної промисловості $є$ виробництво сирого молока, стандартизованого за вмістом мікроорганізмів, що визначає його якість під час зберігання. Це можна досягти лише за умови регулярного очищення та дезінфекції доїльного обладнання та молочного інвентаря (Garvey et al., 2017; Wang et al., 2019).

Метою роботи було дослідити мінімальну бактерицидну концентрацію кислотного мийнодезінфікуючого засобу "Мілкодез” на тест-культурах мікроорганізмів в часовому та температурному діапазонах.

\section{Матеріал і методи досліджень}

Дослідження 3 визначення мінімальної бактерицидної концентрації кислотного мийно-дезінфікуючого засобу "Мілкодез" проводили на паспортизованих тест-культурах мікроорганізмів $S$. aureus ATCC 25923, E. coli 055К59 №3912/41 та $P$. aeruginosa 27/99 згідно 3 методичними рекомендаціями "Рекомендації щодо санітарно-мікробіологічного дослідження змивів 3 поверхонь тест-об'єктів та об'єктів ветеринарного нагляду і контролю” (Yakubchak et al., 2005). Кислотний мийно-дезінфікуючий засіб “Мілкодез” до складу якого входить: ортофосфатна кислота 30\%, вантоцил - 2\%, амоній азотнокислий $-5 \%$ і вода до $100 \%$.

Дослідження бактерицидної дії кислотного засобу проводили за експозиції 2, 5 та 15 хвилин, що відповідає часу, який затрачається на миття і дезінфекцію доїльного устаткування та молочного інвентаря. Розчини різних концентрацій кислотного засобу готували згідно $з$ методичними рекомендаціями “Оцінка придатності та ефективності мийних, дезінфікуючих i мийно-дезінфікуючих засобів для санітарної обробки доїльного устаткування та молочного інвентаря" (Perkii et al., 2012), використовували за температури $20 \pm 5^{\circ} \mathrm{C}$ та $70 \pm 5^{\circ} \mathrm{C}$, що рекомендується для мийнодезінфікуючих засобів для доїльного обладнання (від 60 до $85^{\circ} \mathrm{C}$ ). Температура розчину через 15 хвилин експозиції становила $45 \pm 5^{\circ} \mathrm{C}$, що є необхідним для якісної обробки устаткування (температура води на виході з системи обладнання повинна бути не нижче ніж $\left.40^{\circ} \mathrm{C}\right)$.

\section{Результати та їх обговорення}

У табл. 1 представленні дані дослідження з визначення мінімальної бактерицидної концентрації кислотного засобу “Мілкодез” на тест-культурах мікроорганізмів. При аналізі результатів спостерігаємо, що ріст тест-культури $S$. aureus при експозиції 2 хв спостерігався при розведенні 1:376,5 і більше та концентрації діючої речовини 0,265\% і менше. Відсутність дезінфікуючого впливу засобу “Мілкодез” протягом 5 хв на тест-культуру $S$. aureus починав спостерігатися при розведенні 1:527,1 і більше (концентрації діючої речовини $0,187 \%$ і менше), а також протягом 15 хв 
при розведенні 1:2024,8 і більше та концентрації діючої речовини $0,0493 \%$ і менше.

При розведені дезінфіктанта 1:268,8 та концентрації діючої речовини $0,371 \%$ за експозиції 2 хв спостерігаємо відсутність росту тест-культури $S$. aureus. За розведення $1: 376,5$ концентрація діючої речовини 0,265\% при експозиції 5 хв встановлено відсутність росту тест-культури. При використанні засобу протягом 15 хвилин спостерігаємо відсутній ріст щодо тест культури $S$. aureus при розведенні 1:1466,3 та концентрації 0,0691\%.
В результаті аналізу даних щодо росту тесткультури E. coli встановлено, що при розведенні 1:1033,1 і більше та концентрації речовини 0,0968\% i менше відмічаємо ріст мікроорганізмів за експозиції 2 хв. При розведенні 1:2834,7 і більше (концентрація дезінфіктанта 0,0352\% і менше) спостерігаємо ріст E. coli за експозиції 5 хв, за розведення 1:3698,0 i більше та концентрації $0,0251 \%$ і менше відмічаємо ріст досліджуваної тест-культури при експозиції 15 хвилин. За розведення засобу 1:737,9 та концентрації 0,134\% встановлюємо відсутність росту за експозиції 2 хв.

\section{Таблиця 1}

Мінімальна бактерицидна концентрація кислотного засобу “Мілкодез” на тест-культури мікроорганізмів, $\mathrm{n}=5$

\begin{tabular}{|c|c|c|c|c|c|c|c|c|c|c|c|}
\hline \multirow{3}{*}{$\begin{array}{l}\text { № } \\
\text { П/П }\end{array}$} & \multirow{3}{*}{ Розведення } & \multirow{3}{*}{$\begin{array}{l}\text { Концентрація } \\
\text { речовини, \% }\end{array}$} & \multicolumn{9}{|c|}{ Ріст тест-культур мікроорганізмів протягом часу } \\
\hline & & & \multicolumn{3}{|c|}{ S. aureus } & \multicolumn{3}{|c|}{ E. coli } & \multicolumn{3}{|c|}{$P$. aeruginosa } \\
\hline & & & $2 \mathrm{xB}$ & $5 \mathrm{xB}$ & $15 \mathrm{xB}$ & $2 \mathrm{xB}$ & $5 \mathrm{xB}$ & $15 \mathrm{xB}$ & $2 \mathrm{xB}$ & $5 \mathrm{xB}$ & $15 \mathrm{xB}$ \\
\hline 1 & $1: 50$ & 2 & - & - & - & - & - & - & - & - & - \\
\hline 2 & $1: 70$ & 1,428 & - & - & - & - & - & - & - & - & - \\
\hline 3 & $1: 98$ & 1,020 & - & - & - & - & - & - & - & - & - \\
\hline 4 & $1: 137,2$ & 0,728 & - & - & - & - & - & - & - & - & - \\
\hline 5 & $1: 192,8$ & 0,520 & - & - & - & - & - & - & - & - & - \\
\hline 6 & $1: 268,8$ & 0,371 & - & - & - & - & - & - & - & - & - \\
\hline 7 & $1: 376,5$ & 0,265 & + & - & - & - & - & - & - & - & - \\
\hline 8 & $1: 527,1$ & 0,187 & + & + & - & - & - & - & - & - & - \\
\hline 9 & $1: 737,9$ & 0,134 & + & + & - & - & - & - & - & - & - \\
\hline 10 & $1: 1033,1$ & 0,0968 & + & + & - & + & - & - & - & - & - \\
\hline 11 & $1: 1466,3$ & 0,0691 & + & + & - & + & - & - & - & - & - \\
\hline 12 & $1: 2024,8$ & 0,0493 & + & + & + & + & - & - & - & - & - \\
\hline 13 & $1: 2834,7$ & 0,0352 & + & + & + & + & + & - & - & - & - \\
\hline 14 & $1: 3698,0$ & 0,0251 & + & + & + & + & + & + & - & - & - \\
\hline 15 & $1: 5566,0$ & 0,01799 & + & + & + & + & + & + & - & - & - \\
\hline 16 & $1: 7778,4$ & 0,012856 & + & + & + & + & + & + & - & - & - \\
\hline 17 & $1: 10389,8$ & 0,009182 & + & + & + & + & + & + & + & + & + \\
\hline 18 & $1: 21343,9$ & 0,006559 & + & + & + & + & + & + & + & + & + \\
\hline 19 & \multicolumn{2}{|c|}{$\begin{array}{c}\text { Контроль: вода дистильована } \\
\left.\text { (t } 70 \pm 5^{\circ} \mathrm{C}\right)\end{array}$} & + & + & + & + & + & + & + & + & + \\
\hline
\end{tabular}

Примітки: “+” - наявний ріст бактерій; “-”- відсутній ріст

Ріст тест-культури E. coli був відсутній при використанні засобу протягом 5 та 15 хвилин за розведення 1:2024,8, 1:2834,7 та концентрації засобу "Мілкодез” відповідно 0,0493\%, 0,0352\%.

Щодо тест-культури $P$. aeruginosa - варто зазначити, що ріст мікроорганізмів спостерігався за експозиції 2,5 , та 15 хвилин за розведення $1: 10389,8$ і більше та концентрації засобу “Мілкодез” 0,009182\% і менше. При концентрації дезінфіктанта 0,012856\% та його розведенні 1:7778,4 протягом всіх досліджуваних часових діапазонів помічаємо відсутність росту тест-культури $P$. aeruginosa.

Узагальнюючи результати впливу кислотного засобу “Мілкодез" встановлено, що мінімальними концентраціями його ефективної дії на тест-культури $S$. aureus, E. coli ma P. aeruginosa за експозиції 2 хв$0,371 \%, 5$ хв $-0,265 \%$ та 15 хв - 0,0691\%.

Як видно з рис. 1, зниження температури розчину кислотного засобу призводить до зниження його бактерицидних властивостей. Так, за температури розчину засобу “Мілкодез” $20 \pm 2{ }^{\circ} \mathrm{C}$ загибель тест-культур S. aureus спостерігали за концентрації розчину 4\% протягом 2 хвилин та 3\% - протягом 5 і 15 хвилин. Застосування засобу за температури $70 \pm 5{ }^{\circ} \mathrm{C}$ дозволяло інгібувати золотистий стафілокок за концентрації розчину засобу $0,371 \%$ протягом 2 хвилин дії та $0,265 \%$ і нижче - протягом 5 і 15 хвилин.

Аналогічну ситуацію спостерігали і для тесткультур E. coli i $P$. aeruginosa. Так, за температури розчину $20 \pm 2{ }^{\circ} \mathrm{C}$ інгібування бактерій $E$. coli спостерігали протягом 2 і 5 хвилин за концентрації засобу 2\% і протягом 15 хвилин - за 1,02\%. Водночас за температури розчину засобу “Мілкодез” $70 \pm 5{ }^{\circ} \mathrm{C}$ загибель кишкової палички спостерігали за концентрації кислотного засобу $0,134 \%$ і нижче.

Мікроорганізми P. aeruginosa виявилися найбільш чутливими до кислотного засобу “Мілкодез”. Кислотний засіб за температури $20 \pm 2{ }^{\circ} \mathrm{C}$ інгібував тесткультури $P$. aeruginosa протягом 2 і 5 хвилин за концентрації розчину $0,728 \%$, а протягом 15 хв - за концентрації $0,0352 \%$. Підвищення температури розчину до $70 \pm 5{ }^{\circ} \mathrm{C}$ призводило до загибелі бактерій P. aeruginosa за концентрації засобу 0,01285\% протягом 2,5 i 15 хвилин. 


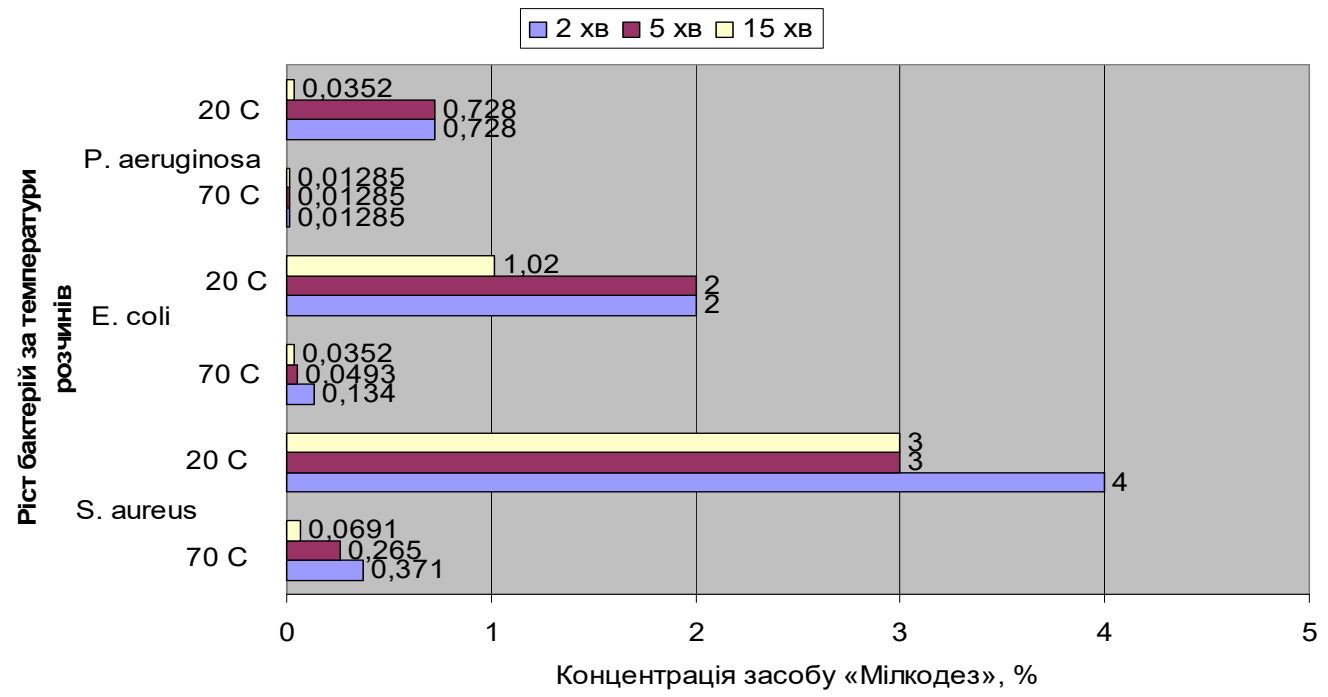

Рис. 1. Мінімальна бактерицидна концентрація кислотного засобу “Мілкодез” на тест-культури мікроорганізмів за різних температур розчинів

Отже, застосування засобу за температури $70 \pm$ $5{ }^{\circ} \mathrm{C}$ дозволяло інгібувати золотистий стафілокок за концентрації розчину засобу $0,371 \%$ протягом 2 хвилин дії та 0,265\% і 0,0691\% - відповідно протягом 5 і 15 хвили. Водночас за температури розчину засобу "Мілкодез" $70 \pm 5{ }^{\circ} \mathrm{C}$ загибель кишкової палички спостерігали за концентрації кислотного засобу 0,0352\%, $0,0493 \%$ та $0,134 \%$ відповідно протягом 2, 5 та 15 хв. Підвищення температури розчину з $20 \pm 5{ }^{\circ} \mathrm{C}$ до $70 \pm$ $5{ }^{\circ} \mathrm{C}$ призводило до загибелі бактерій $P$. aeruginosa за концентрації засобу $0,01285 \%$ в усіх часових діапазонах.

\section{Висновки}

В результаті дослідження встановлено, що мінімальна бактерицидна концентрації кислотного мийнодезінфікуючого засобу “Мілкодез”, яка знешкоджує тест-культури $S$. aureus, E. coli та $P$. aeruginosa становить за температури $20 \pm 5{ }^{\circ} \mathrm{C}$ та експозиції $2 \mathrm{xв}-4 \%$, 5 хв $-3 \%$ та 15 хв - 3\%, а за температури $70 \pm 5{ }^{\circ} \mathrm{C}$ та експозиції 2 хв - 0,371\%, 5 хв - 0,265\% та 15 хв $0,0691 \%$.

Перспективи подальших досліджень. В подальшому планується визначити стійкість мікробних тесткультур, що містяться в біоплівці, до кислотного мийно-дезінфікуючого засобу “Мілкодез”. Провести лабораторні дослідження щодо дослідження білкового індексу та фенольного коефіцієнту кислотного мийнодезінфікуючого засобу “Мілкодез”.

\section{References}

Berhilevych, O.M., Kasianchuk, V.V., Salata, V.Z., Semaniuk, V.I., Kovalchuk, R.L., \& Ostapiuk, M.M. (2010). Mikrobiolohiia moloka i molochnykh produktiv z osnovamy veterynarno - sanitarnoi ekspertyzy. Navchalnyi posibnyk. Sumy. Universytetska knyha (in Ukrainian).
Bogatko, N., Lyasota, V., Bukalova, N., Artemenko, L., Bogatko, L., Salata, V., \& Dashkovskyy, O. (2018). Sanitary and hygienic assessment of milk of cereal different producers in conformity with international requirements. Scientific Messenger of Lviv National University of Veterinary Medicine and Biotechnologies, 20(83), 88-92. doi: 10.15421/nvlvet8317.

Gachak, Yu.R., Gutyj, B.V., Benitska, A., Dyakun, T., Pristantsky, R., Kinitska, L., \& Selskyi, V. (2017). Use of "Amarant" cryoproush in the technology of dairy products of treatment and propofilactic degradation. Scientific Messenger LNUVMB, 19(80), 57-62. doi: 10.15421/nvlvet8012.

Garvey, M., Curran, D., \& Savage, M. (2017). Efficacy testing of teat dip solutions used as disinfectants for the dairy industry Antimicrobial properties. Int J Dairy Technol, 70(2), 179-187 doi: 10.1111/14710307.12344 .

Karpent'er, B.L., Vong, A.S., \& Sepf, O.P. (2008). Bioplenki na poverhnosti oborudovanija. Molochnaja promyshlenost, 6, 33-35 (in Russian).

Kryzhanivskyi, Ya., Holyk, M., \& Perkii, Yu. (2005). Zbirni punkty moloka selianskykh prysadybnykh hospodarstv - obiekty pidvyshchenoho ryzyku. Veterynarna medytsyny Ukrainy, 5, 35-36 (in Ukrainian).

Palii, A.P., \& Synytsia, O.V. (2016). Canitarna obrobka doilno-molochnoho obladnannia. Visnyk KhNTUSH im. P. Vasylenka, 170, 51-55. http://journals.uran.ua/index.php/wissn021/article/vie w/66328 (in Ukrainian).

Perkii, Yu.B., Kryzhanivskyi, Ya.Y, Kryvokhyzha, Ye.M., Motkaliuk, N.F., Kukhtyn, M.D., \& Krushelnytska, N.V (2012). Otsinka prydatnosti ta efektyvnosti myinykh, dezinfikuiuchykh i myinodezinfikuiuchykh zasobiv dlia sanitarnoi obrobky doilnoho ustatkuvannia ta molochnoho inventaria (Metodychni rekomendatsii) Zatverdzhenni naukovotekhnichnoiu radoiu Derzhavnoi veterynarnoi ta fitosanitarnoi sluzhby Ukrainy (in Ukrainian). 
Pushkar, T.D. (2014). Pokrashchennia sanitarnohihiienichnykh pokaznykiv pry dezinfektsii molochno-doilnoho obladnannia pry zastosuvanni ozonovykh tekhnolohii. Ahrarnyi visnyk Prychornomor'ia, 71(2), 49-52 (in Ukrainian).

Wang, X., Demirci, A., Graves, R.E., \& Puri, V.M. (2019). Conventional and Emerging Clean-in-Place Methods for the Milking Systems. Raw Milk, 91-115. doi: 10.1016/B978-0-12-810530-6.00005-5.

Yakubchak, O.M., Kovalenko, V.L., Khomenko, V.I., Denysiuk, H.M., Bondar, T.O., \& Midyk, S.V. (2005).
Rekomendatsii shchodo

sanitarno-

mikrobiolohichnoho doslidzhennia zmyviv $\mathrm{z}$ poverkhon test-obiektiv ta obiektiv veterynarnoho nahliadu i kontroliu. Metodychni rekomendatsii. Kyiv. NAU (in Ukrainian).

Zazharska, N.M. (2016). Bacterial contamination of milk at different temperatures and shelf life. Scientific Messenger LNUVMBT named after S.Z. Gzhytskyj, 18, 3(70), 108-111. doi: 10.15421/nvlvet7025. 